\title{
Effect of short period feed supplementation during early lactation on performance of cows and calves raised in extensive system ${ }^{1}$
}

\section{Cássio Cassal Brauner ${ }^{1}$, Marcelo Alves Pimentel ${ }^{2}$, Leonardo de Melo Menezes ${ }^{2}$, Jean Pierre Martins Machado ${ }^{2}$, José Carlos Ferrugem Moraes $^{3}$}

\author{
1 Programa de Pós-Graduação em Zootecnia - FAEM - UFPel. \\ 2 Departamento de Zootecnia - FAEM - UFPel. \\ ${ }^{3}$ EMBRAPA Pecuária Sul.
}

\begin{abstract}
Thirty-two multiparous Angus cows at moderate body condition score (3 in a $1-5$ scale) received feed supplementation at the beginning of lactation for a short time to determine the effect on milk yield and composition and on performance of cows and calves. Supplementation started on days $22 \pm 3.2$ after calving. The cows were randomly distributed into two groups $(\mathrm{n}=16)$, one group receiving feed supplementation for 35 days (supplemented group), and the other without supplementation (control group). Each cow received $0.6 \%$ of its body weight in individual troughs daily. Both groups were kept in native pasture condition during supplementation period. Milk yield evaluation, performance of cows and calves were controlled on day 0 (initial), day 14 (middle) and day 35 (final) of the supplementation period. There was no effect of feed supplementation on milk yield or on any other milk component in both groups, and on calf performance as well. Milk composition differed among periods, when fat was the highest in the middle of supplementation and lactose was the highest in the end of the period. Supplemented cows presented more daily average weight gain at the final period of supplementation than cows from the control group. Beef cow with moderate body condition score can gain weight during the lactation period as a response to increase of energy availability in a short period without any influence on milk production and composition as well as a consequence on calf performance.
\end{abstract}

Key Words: milk yield, post-calving performance, supplementation

\section{Efeito da suplementação alimentar por um curto period durante o início da lactação sobre o desempenho de vacas e bezerros de corte criados extensivamente}

\begin{abstract}
RESUMO - Trinta e duas vacas Angus multíparas em escore de condição corporal moderada (3 em escala de 1 a 5) receberam suplementação alimentar no início de lactação, por um período curto, para determinar o efeito sobre a produção e composição do leite e o desempenho de vacas e bezerros. A suplementação teve início aos $22 \pm 3,2$ dias após o parto, as vacas foram distribuídas aleatoriamente em dois grupos $(n=16)$, um recebendo de suplementação alimentar durante 35 dias (grupo suplementado), o outro sem suplementação (grupo controle). Cada vaca recebeu diariamente $0,6 \%$ de seu peso corporal em cochos individuais. Ambos os grupos foram mantidos em condição de pastagem nativa durante o período de suplementação A avaliação da produção de leite, desempenho ponderal de vacas e bezerros foram controlados no dia 0 (início); dia 14 (meio) e dia 35 (final) do período de suplementação. Não houve efeito da suplementação alimentar na produção de leite ou de qualquer componente do leite em ambos os grupos, bem como sobre o desempenho de bezerros. Composição do leite foi diferente entre os períodos, onde a gordura foi maior no meio da suplementação e lactose foi maior no final deste período. Vacas suplementadas apresentaram maior ganho de peso médio diário no período final da suplementação do que as vacas do grupo controle. Vacas de corte em escore de condição corporal moderada podem ganhar peso durante o período de lactação em resposta ao aumento da disponibilidade de energia em um curto período, sem qualquer influência sobre a produção de leite, composição ou como conseqüência no desempenho dos bezerros.
\end{abstract}

Palavras-chave: desempenho pós-parto, produção de leite, suplementação

\section{Introduction}

Pre-weaning or lactation periods are very important in the beef cattle, because in this moment cows should be able to develop two important functions: raise their calves and recover from the previous calving with physiologic condition to breed again (Beal et al., 1990; Jenkins et al., 2000). Milking ability of beef cows is one of the main factors influencing weaning weights of calves (Neville, 1962; Fiems et al., 2008). Undernourishment during this 
period frequently results in failure of the cow becoming pregnant (Short et al., 1990).

Reproduction performance is the most important factor in beef cowherd (Hess et al., 2005), in which postpartum anestrus is the main factor affecting reproductive resumption in beef cows (Short et al., 1990). Nutritional stress combined with lactation anestrus (See Williams [1990] for a detailed review) is the primary factor determining the duration of postpartum anestrus in cattle (Short et al., 1990). These factors together with the effect of parity, most likely contributed collectively to cause the extremely long anestrous period in those cows. Interval from calving to first estrus and pregnancy rate in beef cows are influenced by pre-partum nutrition and postpartum nutrition (Randel 1990; Stalker et al., 2006), body condition (Ciccioli et al., 2003; Moraes et al., 2007) and suckling status (Williams et al., 1996).

Cows raised in a range system in poor body condition score (BCS) tend to lose weight and BCS at the beginning of postpartum period; eventually they are thin and with reduced chances to become pregnant again when the breeding season begin. The energetic balance and nutritional condition in this period is the most important factor influencing the postpartum reproduction performance (Wettemann et al., 2003). It is possible that feeding programs to achieve more rapid weight and great body condition in a strategic way would allow cows gain weight, maintain their BCS and finally reduce postpartum interval (Lalman et al., 2000; Cerdótes et al., 2004a; Freetly et al., 2006).

In southern Brazil, the majority of beef cattle production has no supplementary feeding, especially for cows; animals grazing in range condition depend solely on climatic conditions and on what the natural pastures provide. Calving season occurs during the end of the winter and spring seasons, under low forage quality and availability. Under these conditions, most cows are submitted to low nutritional levels during the latter half of gestation in winter, and they are suckling their calves at the time when the breeding season begins (Brauner et al., 2009). Therefore, it results in low reproductive efficiency cowherds (Moraes et al., 2007). This contributed to lower conception rates during the fixed breeding season, resulting in lower biological efficiency (Jenkins et al., 2000).

There is no available study which evaluated the use of a short term period feeding to promote faster weight gain during the early postpartum period. As a result, an important goal for beef cows in the Brazilian production system would be a development of postpartum supplementation program during the early lactation period, allowing cows to achieve or maintain a satisfactory BCS, weight gain which enhance a better postpartum reproduction performance and efficiency of the cowherd. The objective of this study was to determine the effect of extra energy intake for a short period of time during the early postpartum period on performance of cows, and calves, milk production and composition, in beef cows calving in moderate body condition score.

\section{Material and Methods}

Thirty-two Aberdeen Angus cows in moderate body condition score (BCS3), according to a five-class scale $(1=$ extremely thin to $5=$ extremely fat $)$, used by the Rio Grande do Sul state extension service (Moraes et al., 2007), were randomly allotted in two groups $(\mathrm{n}=16)$. One group was fed a concentrate as a supplement for 35 days (fed group) and the other group was not supplemented (control group). Cows in both groups were allotted according to their calving dates. The supplementation period program started on $22 \pm 3.2$ days postpartum. This moment was chosen with the objective to reduce the negative effects of postpartum energy balance (Butler \& Smith, 1989). Furthermore, after 35 days of supplementation (around 60 days after calving), cows would have recovered of previous calve and exhibit physiological conditions to conceive in the next breeding season (Freetly et al., 2006). Another reason to investigate a 35 -day supplementation period was to study a reasonably and feasible period to feed the cows in the beef cattle system, instead of feeding them for all post-partum period, and maybe use this management as an alternative to early weaning which could have negative effects on calf development (Potter \& Lobato, 2003).

Cows were grazed on native pastures and supplemented with $2 \mathrm{~kg} / \mathrm{d}$ concentrate (Table 1). The supplement, on a DM basis, consisted of rice bran $(65 \%)$, soybean hulls $(15 \%)$ and ground corn (20\%). Net metabolizable energy available in the concentrate was $6.34 \mathrm{Mcal} / \mathrm{d}$, providing $61.85 \%$ of nutritional requirements for maintenance $(10.25 \mathrm{Mcal} / \mathrm{d})$, or $110.45 \%$ of additional requirements for lactation during the

Table1 - Chemical composition of supplement and forage ${ }^{1}$

\begin{tabular}{lcc}
\hline Item & Supplement & Forage \\
\hline Dry matter (\%) & 88.6 & 97.2 \\
Ash (\%) & 12.0 & 9.9 \\
Crude protein (\%) & 15.2 & 16.2 \\
Fiber(\%) & 17.7 & 28.8 \\
Total digestible nutrients (\%) & 72.1 & 66.1 \\
Neutral detergent fiber (\%) & - & 61.3 \\
Acid detergent fiber (\%) & - & 34.8 \\
\hline
\end{tabular}

${ }^{1}$ Values expressed in DM basis 
second month since calving (5.74 Mcal/d) and $40.0 \%$ of total requirement for beef cows in second month of lactation (15.99 Mcal/d) according to NRC (2000). The objective of this experiment was to supply cows in a range system an extra energy and to investigate how they would use it: by improving milk production and as a result improving performance of calves or by using it to recover their weight. Both groups were grazed in the same native pasture and, therefore, any difference of the cow performance would be assigned to the treatment effect. Supplement amounts were offered daily in individual feeding stalls. The native pastures included a mixture of bahiagrass (Paspalum notatum), louisiana grass (Axonopus affinis), ryegrass (Lolium multiflorum spp.) and some clover species (Tripholium spp.). Cows had free access to a salt-mineral mixture and water all the time. Similar conditions were created such as cows in this system were grazing where the stocking rate was 0.7 animal units per ha. The forage was collected every 7 days by the hand-puckled method, considering 20 samples/ha (Edlefsen et al., 1960; Silveira et al., 2005).

Milk yield was estimated by a weigh-suckle-weigh procedure, performed on day 0 (initial); on day 14 (middle) and on day 35 (final) as described by Beal (1990) and adapted to this experimental conditions by Pimentel et al. (2006). Briefly, cow-calf pairs were gathered from native pastures to a central handling facility in the morning prior to data collection. Calves were separated at 8:00 a.m. from their dams until 6:00 p.m., then they were reunited with their dams and allowed to nurse. This preliminary separation period and subsequent nursing was designed to leave only residual milk in the mammary gland at the beginning of the measurement period. After nursing, the calves were again separated from their dams and remained apart until 6:00 a.m. the next morning, when they were weighed, allowed to nurse until either satiated or milk was no longer available, and quickly reweighed. The difference among weights was assumed to reflect the milk consumed by the calf and to measure milk produced by the cow during the preceding 12 hours. The 12 -h milk production data were doubled to estimate 24-h milk production. Milk samples $(300 \mathrm{~mL})$ were collected by hand stripping. After mixing, subsamples $(40 \mathrm{~mL})$ were collected and preserved with 2-bromo2-nitropropano-1,3-diol (bronopol). Those samples were analyzed in a laboratory for determinations of lactose, milk fat, and protein content by infrared analysis (Daley et al., 1987). Evaluations of cows and calves weight were taken simultaneously to calculate their performance as average daily gain (ADG). Efficiency of the cow was performed according to the following adjustment: kilograms of calf weight/kilograms of cow weight
(Jenkins \& Ferrell, 2004) in two different moments, at the end of the supplementary feeding and at weaning.

Data were analyzed by using the mixed models procedures of NCSS (2007). Fixed effects included dietary treatment, cow within treatment, period, and the treatment $x$ period interaction. The calving date was used as co-variable. Time course data were analyzed by using the repeated measures within the mixed procedures of NCSS (2007). For animals performance analysis the following model was used:

$\left.\mathrm{Y}_{\mathrm{ijkl}}=\mu+\mathrm{SUPL}_{\mathrm{i}}+\mathrm{b}_{1} \mathrm{DP}_{\mathrm{j}}+\mathrm{MOM}_{\mathrm{k}}+\mathrm{SUPL} \times \mathrm{MOM}_{\mathrm{il}}\right)+\varepsilon_{\mathrm{ijkl}}$, where $\mathrm{Y}_{\mathrm{ijkl}}=$ the value of cow weight, cow ADG, calf weight, calf ADG; $\mu=$ the mean; $\mathrm{SUPL}_{\mathrm{i}}=$ the effect of supplement feeding $(i=$ supplemented or not supplemented $) ; b_{1} \mathrm{DP}_{\mathrm{j}}=$ (covariate of calving date); $\mathrm{MOM}_{\mathrm{k}}=$ fixed effect of moment of lactation ( $\mathrm{k}=$ beginning, middle and end); $\mathrm{SUPL} * \mathrm{MOM}\left({ }_{\mathrm{il}}\right)$, the interaction of treatment and time of lactation, $\varepsilon_{\mathrm{ijkl}}=$ residual errors. The correlations were made by using the Pearson correlation procedure (NCSS, 2007).

\section{Results and Discussion}

Supplemented cows had average daily gain (ADG) higher $(\mathrm{P}<0.05)$ than cows in control group at the third part of supplementation feeding period (Figure 1). With the extra energy available in the diet, cows in the fed group had an energy availability that allowed them to increase their daily weight gain, especially in the middle-final period. Greater

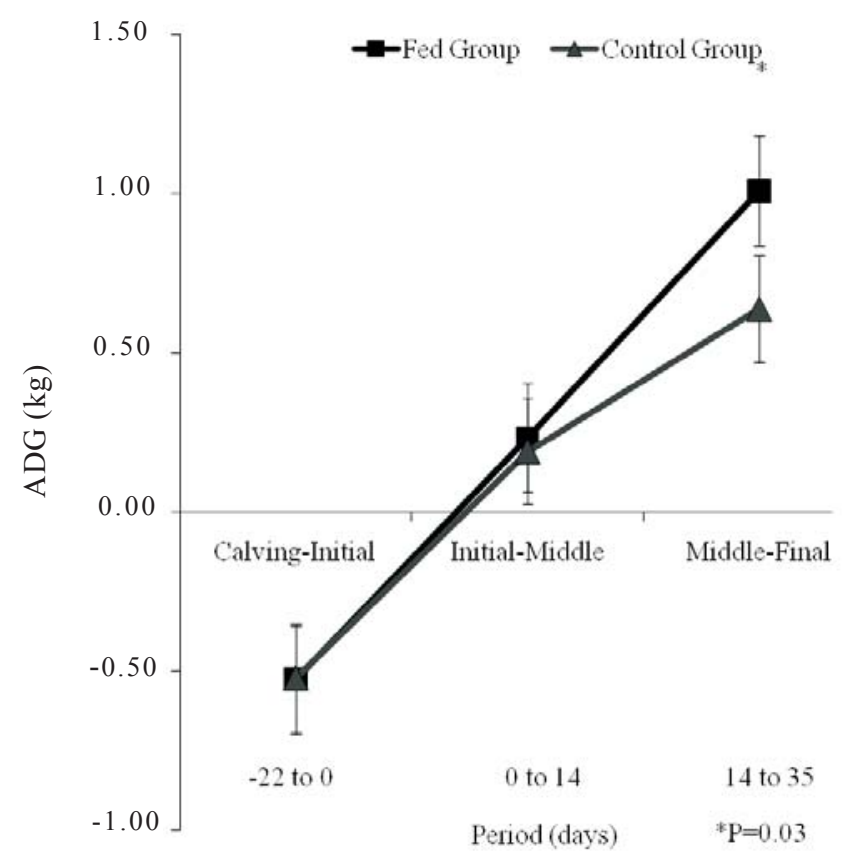

Figure 1 - Cows performance (ADG) during the supplementation period. 
postpartum nutrient intake can enhance the secretion of LH and follicular growth (Perry et al., 1991; Lents et al., 2008), and effects of nutrition on reproduction may be more pronounced in thin cows than in cows with adequate BCS (Richards et al., 1986; Spitzer et al., 1995). It can be hypothesized as a consequence of this result that cows in the fed group could recover from the calving faster than the cows in the control group, achieving a better reproduction performance. The increase of weight gain near to the breeding season could be a signal to the cow brain, meaning that the environment is favorable to another conception (Ciccioli et al., 2003).

Results of performance of the cows suggest that in graze beef production system, the supplementary feeding during a short period, in a strategic moment of postpartum period, could be effective in some conditions to cows improve their performance, serving as a tool to provide better chances to cows become pregnant again. As showed by Ciccioli et al. (2003) and reviewed by Hess et al. (2005), feed intake in beef cows during the postpartum period has an impact and influence on their metabolism. Cows with a good BCS and/or fed rations with different supplementations increased their performance and as a result they could have a better reproductive performance. During this experiment, the BCS was moderate during the entire supplementation feeding period in both groups. After the end of this period until weaning, some cows in both groups increased their BCS, but there were not any cow decreasing their BCS remaining in a moderate status, which is not an impediment for a good reproductive performance in beef cows (Brauner et al., 2009). Cows and calves in both groups had the same performance during the early postpartum period as well as until the end of lactations (Table 2).

Table 2 - Early lactation cow and calf performances $(\mathrm{kg})$ in cows fed a short period of time or not (control)

\begin{tabular}{lcccc}
\hline Item & Fed & Control & SEM & P-value \\
\hline Cow & & & & \\
Calving BW & 444.75 & 430.56 & 11.58 & 0.41 \\
Initial BW & 433.73 & 424.77 & 12.06 & 0.61 \\
Middle BW & 437.23 & 427.77 & 12.44 & 0.61 \\
Final BW & 466.32 & 446.49 & 12.46 & 0.28 \\
Weaning weight & 463,31 & 453.50 & 10.03 & 0.50 \\
Calf & & & & \\
Birth weight & 37.4 & 36.2 & 0.87 & 0.29 \\
Initial BW & 55.89 & 54.40 & 1.96 & 0.61 \\
Middle BW & 65.95 & 65.10 & 1.89 & 0.76 \\
Final BW & 93.40 & 91.89 & 2.38 & 0.67 \\
Weaning weight & 189.79 & 188.19 & 3.87 & 0.77 \\
ADG calving-initial & 0.949 & 0.706 & 0.112 & 0.15 \\
ADG initial-middle & 0.831 & 0.850 & 0.048 & 0.78 \\
ADG middle-final & 0.968 & 0.919 & 0.036 & 0.34 \\
ADG final-weaning & 0.740 & 0.773 & 0.023 & 0.32 \\
\hline
\end{tabular}

Cows responded to extra energy intake in a short period, partitioning nutrients away from milk production, due to the recovery of their nutritional condition or the body tissue energy reserve stores. This fact is likely due to the response of fed group ADG in the end of the supplementation period (Figure 1) and also of the lack of difference in milk production (Table 3 ). It is possible that beef cows on moderate BCS had a different nutrient partitioning, prioritizing the body tissue energy reserves stores instead of using it for milk production. Short et al. (1990) proposed an approximate order of priority for partitioning of nutrients, in which the nutrients are partitioned first to maintain life of the cow, then to raise a calf with milk and finally to propagate the species. The cows in this experiment maybe fit in the beginning of that rank, where cows are accumulating basic energy reserves, which occur before lactation. After cows have their reserves restored and have energy enough for reproduction, they start the reproduction function again.

Calves performance is mainly reflected by milk production of dams. In beef cows, this effect is observed as the main input in calf diet until the fourth month (Robinson et al., 1978; Pimentel et al., 2006). Fiems et al. (2008) found that calves weight during this period is largely dependent on milk intake, explaining $65 \%$ of the daily weight gain. In this study, calves in both groups had the same performance during the supplementation period and at the weaning. This result indicated that cow feed intake does not affect calves performance.

A useful method to measure cow/calf production and interaction during the pre-weaning period is to calculate cow efficiency (Jenkins \& Ferrell, 2004). Cow efficiency did not differe $(\mathrm{P}>0.05)$ among groups. It was $20.16 \% \pm 0.65$ and $20.68 \% \pm 0.65$, at end of the supplementation feeding period and $40.94 \pm 1.25 \%$ and $42.04 \pm 1.25 \%$, at weaning in fed and control group, respectively. This result shows that when cows are fed extra energy during a short period, this is not able to modify the cow/calf relationship and calves seems to be totally out of the treatment effects, only using the milk raised by their dams and use this in their development, especially during the feeding period.

Although ADG of cows were different during the last third of the supplementation period, it could not be observed significant differences in their body weight during the supplementary feeding period and at weaning. Maybe, if a larger amount of energy were used, it could have had an effect on body weight. However, all the production system would be different; thereby the milk production also would be affected by the supplementation, as described in other studies (Lalman et al., 2000; Ciccioli et al., 2003). 
Table 3 - Milk production and milk component production as influenced by supplementation fed for a short period of time

\begin{tabular}{|c|c|c|c|c|c|c|}
\hline Item & & Milk yield & $\%$ Fat & $\%$ Protein & $\%$ Lactose & Milk energy ${ }^{h}$ \\
\hline \multirow[t]{2}{*}{ Treatment } & Fed & $7.53 \pm 0.31$ & $4.21 \pm 0.36$ & $3.20 \pm 0.08$ & $4.81 \pm 0.12$ & $5.57 \pm 0.38$ \\
\hline & Control & $7.17 \pm 0.31$ & $4.44 \pm 0.36$ & $3.36 \pm 0.08$ & $4.54 \pm 0.12$ & $5.50 \pm 0.38$ \\
\hline & Fed & $7.08 \pm 0.56$ & $3.56 \pm 0.54$ & $3.15 \pm 0.09$ & $4.82 \pm 0.16$ & $4.87 \pm 0.64$ \\
\hline \multirow{2}{*}{ Initialj $^{j}$} & Control & $6.95 \pm 0.56$ & $4.79 \pm 0.54$ & $3.53 \pm 0.09$ & $4.40 \pm 0.16$ & $5.36 \pm 0.64$ \\
\hline & Average & $7.02 \pm 0.39$ & $4.18 \pm 0.38 \mathrm{~cd}$ & $3.34 \pm 0.07$ & $4.61 \pm 0.11 b$ & $5.11 \pm 0.45 d$ \\
\hline \multirow{2}{*}{ Middle $\mathrm{k}^{\mathrm{k}}$} & Average & $8.1 \pm 0.39$ & $5.06 \pm 0.38 \mathrm{c}$ & $3.32 \pm 0.07$ & $4.26 \pm 0.11 b$ & $6.50 \pm 0.45 c$ \\
\hline & Fed & $7.4 \pm 0.56$ & $3.86 \pm 0.54$ & $3.14 \pm 0.09$ & $5.15 \pm 0.16$ & $5.33 \pm 0.64$ \\
\hline \multirow[t]{2}{*}{ Final $^{1}$} & Control & $6.56 \pm 0.56$ & $3.58 \pm 0.54$ & $3.23 \pm 0.09$ & $5.16 \pm 0.16$ & $4.67 \pm 0.64$ \\
\hline & Average & $6.99 \pm 0.39$ & $3.72 \pm 0.38 \mathrm{~d}$ & $3.18 \pm 0.07$ & $5.16 \pm 0.11 \mathrm{a}$ & $5.00 \pm 0.45 \mathrm{~d}$ \\
\hline General average & & 7.35 & 4.32 & 3.28 & 4.67 & 5.53 \\
\hline
\end{tabular}

$\mathrm{c}>\mathrm{d} \mathrm{P}<0.05 ; \mathrm{a}>\mathrm{b} \mathrm{P}<0.0001$.

${ }^{\mathrm{h}}$ Milk energy $(\mathrm{Mcal} / \mathrm{dia})$ calculated as $[(0.092 \times$ fat percent $)+(0.049 \times$ solids not fat percent $)-0.0569] \times$ milk yield, in NRC $(2000)$.

j Day 0 in the supplementation feed period or day $22.3 \pm 3.2$ postpartum.

${ }^{k}$ Day 14 in the supplementation feed period or day $36.3 \pm 3.2$ postpartum.

${ }^{1}$ Day 35 in the supplementation feed period or day $57.3 \pm 3.2$ postpartum.

Several investigators have reported that in postpartum beef cows, increased energy intake corresponds to increased milk production, similarly to dairy cattle (Perrry et al., 1991; Marston et al., 1995; Ciccioli et al., 2003; Cerdótes et al., 2004b). On the other hand, some studies did not detect any differences in milk production in the beginning of lactation (Lalman et al., 2000; Bottger et al., 2002; Lake et al., 2005). It was not detect any difference in milk production in this study, and the results were similar to those found in other studies using Angus cows (Jenkins and Ferrell, 1992; Marston et al., 1995) and in studies in the same environment as reported by Pimentel et al. (2006). A possible explanation for the difference between this study and those studies which found differences in milk yield is the duration of the feed period. In the present study, this period was restrict and short ( 35 days) whereas the others were performed during all the postpartum period, allowing the cows to recover their physiologic condition (gaining weight and increase their BCS) and after that increase their milk yield (Lalman et al., 2000; Cerdótes et al., 2004b).

There are several experiments on milk production in beef cows with different methodology. Beal et al (1990) found that the correlation is high and similar, 0.75 and 0.76 for the direct and indirect method, respectively. The indirect method (weight-suckle-weight) could underestimate the milk yield (Jenkins \& Ferrell, 1992), however this method measures exactly what the calf consumes. The direct method (milking machine) gives a measure of the milk production capacity by cows but does not represent the actual milk consumed by calves, what can overestimate the milk yield (Freetly et al., 2006). Furthermore, it was also not detect differences in calves performance during the supplement period, which is when milk is the most important feed which allow calf growth (Robinson et al., 1978; Pimentel et al., 2006), so this result can support that the milk production did not differ among groups.

There was no effect $(\mathrm{P}>0.05)$ of supplementation feed for a short period on milk production or any milk component in both groups (Table 3). In beef cows, lactation has a different pattern than in dairy cows. In beef cows, milk production is modulated for the calf ingestion capacity, in other words, milk production is limited by calf capacity of ingestion. Cows can spend the energy available to produce more milk in another physiological function. So, there could be another evidence explaining that no difference in milk production was detected in this study and unless cows had large amounts of energy available to expend for milk production, they would use this energy for themselves.

Milk composition and milk energy was similar to that found in different studies (Lalman et al., 2000; Lake et al., 2005). In this experiment, supplementary feeding in a short period supplied calves with the same energy amount in both groups (Table 3 ). Fat production and milk energy available were higher in the middle of the supplementation period. This might have happened because maximum milk production occurred at the same moment $(36 \pm 3.2$ days postpartum). Milk energy was highly correlated (0.97) with fat $(\mathrm{P}<0.0001)$ and $(0.47)$ with lactose $(\mathrm{P}<0.01)$, indicating that $97 \%$ of the variation in the milk energy is due to the variation in the fat production and $47 \%$ with lactose. 


\section{Conclusions}

Beef cows in moderate body condition score can gain weight during the lactation period as a response to increase in energy availability for short period, without any influence on milk production, composition or as a consequence in the calf performance. It is suggested that if cows are in a moderate BCS at calving, increasing energy postpartum (near to the next breeding season) is effective in improving weight gain, allowing the cows to recover their reproductive condition which results in a better reproductive performance.

\section{References}

BEAL, W.E.; NOTTER, D.R.; AKERS, R.M. Techniques for estimation of milk yield in beef cows and relationships of milk yield to calf weight gain and post partum reproduction. Journal of Animal Science, v.68, p.937-943, 1990.

BRAUNER, C.C.; PIMENTEL, M.A.; LEMES, J.S. et al. Postpartum reproductive performance of beef cows in moderate body condition submitted to estrus induction/ synchronization. Revista Brasileira de Zootecnia, v.38, n.1 p.99-103, 2009.

BOTTGER, J.D.; HESS, B.W.; ALEXANDER, B.M. et al. Effects of supplementation with high linoleic or oleic cracked safflower seeds on postpartum reproduction and calf performance of primiparous beef heifers. Journal of Animal Science, v. 80, p.2023-2030, 2002.

BUTLER, W.R.; SMITH, R.D. Interrelationships between energy balance and postpartum reproductive function in dairy cattle. Journal of Dairy Science, v.72, p.767-783, 1989.

CERDÓTES, L.; RESTLE, J.; ALVES FILHO, D.C. et al. Performance of beef calves produced by cows submitted to different feeding managements, weaned at 42 or 63 days of age. Revista Brasileira de Zootecnia, v.33, n.3 p.597-609, 2004 .

CERdótes, L.; RESTle, J.; ALVES FILHO, D.C. et al. Production and composition of milk of cows of four genetic groups submitted to two feeding managements during the lactation period. Revista Brasileira de Zootecnia, v.33, n.3, p.610-622, 2004.

CICCIOLI, N.H.; WETTEMANN, R.P.; SPICER, L.J. Influence of body condition at calving and postpartum nutrition on endocrine function and reproductive performance of primiparous beef cows. Journal of Animal Science, v.81, p.3107-3120, 2003

DALEY, D.R.; McCUSKEY A.; BAILEY, C.M. Composition and yield of milk from beef-type Bos taurus and Bos indicus x Bos Taurus. Journal of Animal Science, v.64, p.373-384, 1987.

EDLEFSEN, J.L.; COOK, C.W.; BLAKE, J.T. Nutrient content of diet as determinate by hand puckled and esophageal fistula samples. Journal of Animal Science, v.19, p.560-567, 1960.

FIEMS, L.O.; VAN CAELENBERGH, W.; CAMPENEERE, S.D. et al. Effect of dam factors on milk intake and performance of Belgian Blue suckling calves. Animal, v.2, p.135-140, 2008

FREETLY, H.C.; NIENABER, J.A.; BROWN-BRANDL, T. Partitioning of energy Composition and yield of milk from beef-type Bos taurus and Bos indicus x Bos taurus dams. Journal of Animal Science, v. 84, p.2157-2162, 2006.

HESS, B.W.; LAKE, S.L.; SCHOLLJEGERDES, E.J. et al. Nutritional controls of beef cow reproduction. Journal of Animal Science, v.83, p.E90-E106, 2005.
JENKINS, T.G.; FERRELL, C.L. Preweaning efficiency for mature cows of breed crosses from tropically adapted Bos indicus and Bos taurus and unadapted Bos taurus breeds. Journal of Animal Science, v.82, p.1876-1881, 2004.

JENKINS, T.G.; FERRELL, C.L.; ROBERTS, A.J. Lactation and calf weight traits of mature crossbred cows fed varying daily levels of metabolizable energy. Journal of Animal Science, v.78, p.7-14, 2000 .

JENKINSTG, T.G.; FERRELL, C.L. Lactation characteristics of nine breeds of cattle fed various quantities of dietary energy. Journal of Animal Science, v.70, p.1652-1660, 1992.

LAKE, S.L.; SCHOLLJEGERDES, E.J.; ATKINSON, R.L. et al Body condition score at parturition and postpartum supplemental fat effects on cow and calf performance. Journal of Animal Science, v.83, p.2908-2917, 2005.

LALMAN, D.L.; WILLIAMS, J.E.; HESS, B.W. et al. Effect of dietary energy on milk production and metabolic hormones in thin, primiparous beef heifers. Journal of Animal Science, v.78, p.530-538, 2000.

LENTS, C.A.; WHITE, F.J.; CICCIOLI, N.H. et al. Effects of body condition score at parturition and postpartum protein supplementation on estrous behavior and size of the dominant follicle in beef cows. Journal of Animal Science, v. 86 , p.2549-2556, 2008.

MARSTON, T.T.; LUSBY, K.S.; WETTEMANN, R.P. et al. Effects of feeding energy or protein supplements before or after calving on performance of spring-calving cows grazing native range. Journal of Animal Science, v.73, p.657-664, 1995.

MORAES, J.C.F.; SOUZA, C.J.H.; JAUME, C.M. Body condition score to predict the postpartum fertility of crossbred beef cows. Pesquisa Agropecuária Brasileira, v.42, p.741-746, 2007.

NCSS, NCSS: statistical system for Windows: user's guide V. Kaysville, 2007. 565p

NEVILLE, W.E. Influence of dam's milk production and other factors on 120-and 240-day weight of Hereford calves. Journal of Animal Science, v.21, p.315-320, 1962.

NATIONAL RESEARCH COUNCIL - NRC. Nutrient requirements of beef cattle. 7. rev. ed. Washington, D.C.: National Academic Press, 2000. 248p.

PERRY, R.C.; CORAH, L.R.; COCHRAN, R.C. et al. Influence of dietary energy on follicular development, serum gonadotropins, and first postpartum ovulation in suckled beef cows. Journal of Animal Science, v.69, p.3762-3773, 1991.

PIMENTEL, M.A.; MORAES, J.C.F.; JAUME, C.M. et al. Lactation performance of Hereford cows raised in a range system in the state of Rio Grande do Sul. Revista Brasileira de Zootecnia, v.35, p.1-11, 2006.

POTTER, B.A.A.; LOBATO, J.F.P. Performance and carcass traits of Braford steers weaned at 100 or 180 days and slaughtered at 13-14 months old. Revista Brasileira de Zootecnia, v.32, n.5, p.1220-1226, 2003.

RANDEL, R.D. Nutrition and postpartum rebreeding in cattle. Journal of Animal Science, v.68, p.853-862, 1990.

RICHARDS, M.W.; SPITZER, J.C.; WARNER, M.B. Effect of varying levels of postpartum nutrition and body condition at calving on subsequent reproductive performance in beef cattle. Journal of Animal Science, v.62, p.300-306, 1986.

ROBISON, O.W.; YUSUFF, M.K.M.; DILlARD, E.U. Milk production in Hereford cows: I. Means and correlations. Journal of Animal Science, v.47, p.131-136, 1978.

SHORT, R.E.; BELLOWS, R.A.; STAIGMILLER, J.G. et al. Physiological mechanisms controlling anestrus and infertility in pospartum beef cattle. Journal of Animal Science, v. 68 , p.799-815, 1990 .

SILVEIRA, V.C.P.; VARGAS, A.F.C.; OLIVEIRA, J.O.R. et al Quality of natural pasture evalueted with different methods and soils at the Apa of Ibuirapuitã, Brazil. Revista Ciência Rural, v.35, n.3, p.582-588, 2005 . 
SPITZER, J.C.; MORRISON, D.G.; WETTEMANN, R.P. et al. Reproductive responses and calf birth and weaning weights as affected by body condition at parturition and postpartum weight gain in primiparous beef cows. Journal of Animal Science, v.73, p.1251-1257, 1995.

STALKER, L.A.; ADAMS, D.C.; KLOPFENSTEIN, T.J. et al. Effects of pre- and postpartum nutrition on reproduction in spring calving cows and calf feedlot performance. Journal of Animal Science, v.84, p.2582-2589, 2006.
WETtEMANN, R.P.; LENTS, C.A.; CiCCIOLI, N.H. et al. Nutritional- and suckling-mediated anovulation in beef cows. Journal of Animal Science, v.81, p.E48-E59, 2003.

WILLIAMS, G.L. Suckling as a regulator of post partum rebreeding in cattle: a review. Journal of Animal Science, v. 68, p.831-852, 1990.

WILLIAMS, G.L.; GAZAL, O.S.; GUZMAN, G.A. et al. Mechanisms regulating suckling-mediated anovulation in the cow. Animal Reproduction Science, v.42, p.289-297, 1996. 